\title{
PERTANGGUNGJAWABAN DIREKSI BUMN TERHADAP PERBUATAN YANG MENGAKIBATKAN KERUGIAN KEUANGAN NEGARA ${ }^{1}$
}

\author{
Henny Juliani \\ Fakultas Hukum Universitas Diponegoro \\ Jl. Prof. Soedarto, SH. Tembalang, Semarang \\ Email: hennyjuliani.fhundip@gmail.com
}

\begin{abstract}
Directors of state owned company can be prosecuted because of suspected on their actions which cause state finances loss. The objectives of this research is to find out responsibilities of directors which cause state finances loss. This research used normative juridical method. The research result that the directors of state owned company were assumed as state officers. State owned company assets were intrepreted as state assets, as well as state loss was intrepreted as state finance loss. In administrative law, when directors of state owned company do an action that cause state finances loss, they are obliged returning the loss, but in criminal law, returning the loss will not eliminate the pinalty of the criminal.
\end{abstract}

Keywords: Responsibilities; Directors of State Owned Company; State Finances Loss.

\begin{abstract}
Abstrak
Pengelolaan BUMN tidak bisa dilepaskan dari peranan direksi. Direksi dapat dituntut di pengadilan karena disangka/didakwa telah melakukan tindakan yang merugikan keuangan negara akibat perbuatannya mengelola BUMN. Penelitian ini bertujuan untuk mengetahui pertanggungjawaban direksi BUMN terhadap perbuatan yang mengakibatkan kerugian keuangan negara. Metode penelitian yang digunakan adalah yuridis normatif. Hasil penelitian menemukan bahwa Direksi BUMN dipadankan dengan penyelenggara negara (pejabat negara) yang memiliki fungsi strategis. Kekayaan BUMN diintepretasikan sebagai keuangan negara, dan kerugian negara diintepretasikan sama dengan kerugian keuangan negara. Dalam Hukum Administrasi Negara, apabila Direksi BUMN melakukan perbuatan yang mengakibatkan kerugian keuangan negara, maka diwajibkan mengembalikan kerugian tersebut, namun dalam Hukum Pidana (tindak pidana korupsi), pengembalian kerugian keuangan negara tidak menghapuskan pidana pada pelaku tindak pidanatersebut.
\end{abstract}

Kata kunci: Pertanggungjawaban; Direksi BUMN; Kerugian Keuangan Negara.

\section{A. Pendahuluan}

1. Latar Belakang Permasalahan

Undang-undang Dasar Negara

Republik Indonesia Tahun 1945 Pasal 4 ayat

(1) memberikan kewenangan kepada Presiden dalam menjalankan kekuasaan pemerintahan untuk mencapai tujuan bernegara, yaitu menyejahterakan rakyat Ketentuan tersebut dirinci lebih lanjut dalam Pasal 33 yang menjadi dasar pelaksanaan tugas konstitusional bagi seluruh komponen bangsa, termasuk BUMN.

Banyak kalangan berpendapat, perusahaan BUMN merupakan kekuatan dan penggerak ekonomi luar biasa. Di Singapura dan Malaysia, BUMN berkontribusi besar dalam kegiatan ekonomi. Di Indonesia BUMN masuk di sejumlah sektor atau bidang usaha yang beragam, dari perbankan, energi, pangan, infrastruktur, serta perhubungan, baik laut, darat, maupun udara. Sebanyak 118 BUMN pada 2015 dengan total aset Rp 5.395 triliun tentu dapat memberikan kontribusi yang lebih besar bagi pertumbuhan ekonomi 2016 jika mampu bersinergi dalam mengelola bidang usaha. Aset BUMN juga diperkirakan

1. Artikel hasil penelitian dengan sumber dana PNBP Fakultas Hukum Universitas Diponegoro Tahun 2016 
bisa lebih besar melalui proses revaluasi aset BUMN. ${ }^{2}$ Banyak proyek terus digarap BUMN. Sebagai gambaran, total nilai proyek BUMN-yang berjangka waktu 1-3 tahun per akhir 2015 mencapai Rp 795,9 triliun. Realisasi hingga akhir 2015 sebesar Rp 248,5 triliun. Pada 2016, diproyeksikan ada 62 proyek strategis yang dikerjakan BUMN, dengan nilai lebih kurang Rp 347,2 triliun. $^{3}$

Pengelolaan/pengurusan BUMN tidak bisa dilepaskan dari peranan direksi, karena direksi adalah organ BUMN yang bertanggung jawab atas pengurusan BUMN untuk kepentingan dan tujuan BUMN, serta mewakili BUMN baik di dalam maupun di luar pengadilan. Kegigihan direksi dalam memimpin BUMN dengan mengedepankan prinsip-prinsip profesionalitas, profitabilitas, efisiensi, dan inovasi akan memberikan dampak positif bagi BUMN itu sendiri dalam menjalankan fungsi sebagai penyelenggara layanan publik dan agen pembangunan. Hal tersebut antara lain dapat dilihat pada diri Ignasius Jonan pada waktu memimpin PT Kereta Api Indonesia (Persero). Di sisi yang lain direksi BUMN dapat juga dituntut di pengadilan karena disangka/didakwa telah melakukan tindakan yang merugikan keuangan negara akibat perbuatannya dalam mengelola/mengurus BUMN yang dipimpinnya. Kasus terakhir adalah kasus R.J. Lino. Richard Joost Lino (R.J. Lino) adalah direktur utama PT Pelindo II (Persero) yang resmi diberhentikan dari jabatannya oleh pemegang saham pada tanggal 23 Desember 2015, setelah KPK menetapkan Lino sebagai tersangka dalam kasus dugaan korupsi dalam pengadaan quay container crane (QCC) tahun 2010.

Berkaitan dengan pentingnya direksi dalam mengurus BUMN yang dipimpinnya serta tanggung jawab dan risiko yang diembannya dalam mengelola kekayaan negara, maka akan dilakukan penelitian dengan mengkaji permasalahan, antara lain: (1) bagaimana terminologi keuangan negara dan kerugian keuangan negara menurut peraturan perundang-undangan?, dan (2) bagaimana pertanggungjawaban direksi BUMN terhadap perbuatan yang mengakibatkan kerugian keuangan Negara?.

\section{Metode Penelitian}

Penelitian ini merupakan penelitian hukum, yang mengkaji dari sudut pandang hukum dengan menggunakan pendekatan yuridis normatif, karena masalah yang akan diteliti tersebut berhubungan erat dengan law in books. Penelitian hukum normatif merupakan penelitian kepustakaan, yaitu penelitian yang dilakukan dari data sekunder. Menurut Ronny Hanitijo Soemitro, data sekunder di bidang hukum (dipandang dari sudut kekuatan mengikatnya), dapat dibedakan menjadi bahan-bahan hukum primer, bahan-bahan hukum sekunder, dan bahan hukum tersier. ${ }^{4}$ Oleh karena itu, spesifikasi penelitian yang digunakan adalah deskriptif analitis, yang selanjutnya bahanbahan tersebut akan dianalisis secara kualitatif.

\section{Kerangka Teori \\ a. Konsep Negara Kesejahteraan dan Peran BUMN}

Indonesia menganut konsep negara hukum baru yang lebih dinamis yakni yang dikenal dengan istilah welfare state (negara kesejahteraan) atau negara hukum materiil. Di dalam welfare state pemerintah itu diserahi bestuurzorg yaitu penyelenggaraan kesejahteraan umum. ${ }^{5}$ Berkaitan dengan konsep negara kesejahteraan yang merupakan revisi dari konsep negara pasif, Asshiddiqie sebagaimana dikutip oleh W Riawan Tjandra menguraikan bahwa dalam konsep negara kesejahteraan ini, negara dituntut untuk memperluas tanggung jawabnya kepada masalah-masalah sosial ekonomi yang dihadapi rakyat banyak. ${ }^{6}$

Soekanto dalam W. Riawan Tjandra menyatakan apabila semula negara hanya dipandang sebagai instrument of power, maka mulai timbul aliran-aliran yang menganggap negara sebagai agency of service, maka timbullah konsep welfare state yang terutama memandang manusia tidak hanya sebagai individu, akan tetapi juga sebagai anggota

\footnotetext{
2. Harian Kompas, 13 Februari 2016

3. Ibid

4. Ronny Hanityo Soemitro, 1994, Metodologi Penelitian Hukum dan Yurimetri, Jakarta, Ghalia lndonesia, hlm 11-12

5. SF Marbun dan Moh. Mahfud MD, 1987, Pokok-pokok Hukum Administrasi Negara, Yogyakarta, Liberty, hlm 45

6. W Riawan Tjandra, 2008, Hukum Administrasi Negara, Yogyakarta, Penerbit Universitas Atma Jaya, hlm 9.
} 
atau warga dari kolektiva dan bahwa manusia bukanlah semata-mata merupakan alat kepentingan kolektiva akan tetapi juga untuk tujuan diri sendiri. ${ }^{7}$

BUMN sebagai kepanjangan tangan pemerintah dalam penyelengggaraan layanan publik sekaligus sebagai agen pembangunan mempunyai peran penting untuk mewujudkan kesejahteraan rakyat, termasuk aset negara karena negara turut serta dalam penyertaan modal pada BUMN tersebut.

Pengelolaan BUMN sejalan dengan agensifikasi apabila dilihat dari penekanannya terhadap tata kelola yang lebih memerhatikan prinsip efisiensi dan efektivitas. Oleh karena itu, teori agensi sangat mendukung kinerja BUMN. Agency theory merupakan teori yang menjelaskan tentang hubungan kontraktual antara pihak yang mendelegasikan pengambilan keputusan tertentu (principal/ pemilik/pemegang saham) dengan pihak yang menerima pendelegasian tersebut (agent/direksi/manajemen). ${ }^{8}$ Menurut Misahardi Wilamarta dalam Ridwan Khairandy dan Camelia Malik, teori agensi memberikan pandangan yang terbaru terhadap good corporate governance ( $G C G)$, yaitu para pendiri perseroan dapat membuat perjanjian yang seimbang antara principal (pemegang saham) dengan agen (direksi). Teori ini muncul setelah fenomena terpisahnya kepemilikan perusahaan dengan pengelolaan, terutama pada perusahaanperusahaan besar yang modern. ${ }^{9}$

Menurut Pasal 2 Keputusan Menteri Negara/Kepala Badan Penanaman Modal dan Pembinaan BUMN Nomor: KEP- 23/MPM.PBUMN/2000 tentang Pengembangan Praktik GCG dalam Perusahaan Perseroan (PERSERO), GCG adalah prinsip korporasi yang sehat, yang perlu diterapkan dalam pengelolaan perusahaan, yang diselenggarakan semata-mata demi menjaga kepentingan perusahaan dalam rangka mencapai maksud dan tujuan perusahaan.

\section{b. Pertanggungjawaban Pejabat dalam Pelaksanaan Fungsi Jabatan \\ Menurut Philipus M. Hadjon, tanggung} jawab pejabat dalam melaksanakan fungsinya dibedakan antara tanggung jawab jabatan dan tanggung jawab pribadi. Tanggung jawab jabatan berkenaan dengan legalitas (keabsahan) tindak pemerintahan. Tanggung jawab pribadi berkenaan dengan maladministrasi dalam penggunaan wewenang maupun public service. Pembedaan antara tanggung jawab jabatan dan tanggung jawab pribadi atas tindak pemerintahan membawa konsekuensi yang berkaitan dengan tanggung jawab pidana, tanggung gugat perdata dan tanggung gugat tata usaha negara (TUN). Tanggung jawab pidana adalah tanggung jawab pribadi. ${ }^{10}$

Mencermati delik pidana penyalahgunaan kewenangan, kesempatan atau sarana yang ada karena jabatan yang dapat merugikan keuangan negara, Hernold Ferry Makawimbang menyatakan bahwa kata kunci yang harus dijawab adalah "apa kewenangan itu, dan bagaimana kesempatan atau sarana yang ada karena jabatan itu", sehingga dapat disalahgunakan dan dapat merugikan keuangan negara. Jika dilihat dari kata-kata tersebut mempunyai pengertian "kewenangan yang diperoleh karena jabatan" dan jabatan tersebut mempunyai akses terhadap keuangan negara. ${ }^{11}$

Kerugian negara menurut UndangUndang Nomor 1 Tahun 2004 tentang Perbendaharaan Negara Pasal 1 angka 22 adalah kerugian negara/daerah yang meliputi unsur-unsur kekurangan uang, surat berharga dan barang, yang nyata dan pasti jumlahnya sebagai akibat melawan hukum baik sengaja maupun lalai. Menurut Agus Ngadino dan Iza Rumesten RS, dalam prakteknya, pengelola pemerintahan baik di pusat maupun di daerah yang melakukan tindakan melawan hukum dan mengakibatkan kerugian negara/daerah dapat dikenakan penggantian atas kerugian negara dimaksud. Dalam bidang pemerintahan pihak yang dapat menjadi subyek penggantian kerugian negara/daerah

\footnotetext{
7. Ibid, hlm 11-12

8. Ridwan Khaerandy dan Camelia Malik, 2007, Good Corporate Governance, Yogyakarta, Total Media, hlm 16.

9. Ibid

10. Philipus M. Hadjon,, 2011, Hukum Administrasi dan Tindak Pidana Korupsi, Yogyakarta, Gadjah Mada University Press, hlm 16-17.

11. Hernold Ferry Makawimbang, 2014, Kerugian Keuangan Negara, Yogyakarta, Thafa Media, hlm 38.
} 
adalah pihak yang mempunyai kewenangan terkait dengan pengelolaan keuangan negara meliputi Presiden, menteri keuangan, menteri/pimpinan lembaga, kepala daerah, bendahara, pegawai negeri bukan bendahara, dan pejabat lain yang mendapat kewenangan dalam pengelolaan keuangan negara/daerah. Berdasarkan kewenangan yang diberikan menurut ketentuan hukum administrasi, dimana menurut hukum administrasi dikenal tiga cara memperoleh wewenang yaitu atribusi, delegasi, dan mandat.

Selain itu, dalam hal kerugian negara, maka negara bertindak selaku pihak penggugat terhadap persero, perusahaan umum atau perseroan terbatas lainnya yang menimbulkan kerugian terhadap keuangan negara dalam kedudukan selaku pihak penggugat. $^{12}$

Indroharto dalam Ridwan HR menyatakan bahwa BUMN/BUMD dimasukkan sebagai "instansi pemerintah".13 Pendapat berbeda dinyatakan oleh Arifin P. Soeria Atmadja yang menegaskan bahwa status hukum Persero (BUMN) adalah murni badan hukum perdata, demikian pula hubungan usaha diatur menurut hukum perdata serta tidak memiliki fasilitas negara. Nomenklatur yang berlaku pada lembaga pemerintah sama sekali tidak berlaku pada Persero, termasuk di dalamnya status hukum pegawai Persero termasuk direksinya adalah pegawai swasta biasa. ${ }^{14}$

Hekinus Manao sebagaimana dikutip oleh Jamin Ginting menyatakan bahwa pemahaman keuangan negara dalam BUMN atau BUMD sering diidentikkan dengan aset pemerintah sehingga seluruh piutang maupun utang BUMN/BUMD adalah piutang maupun utang dari pemerintah, padahal pemahaman yang benar adalah kekayaan yang dipisahkan oleh pemerintah pada BUMN/BUMD adalah bagian dari kekayaan negara. Kekayaan negara tersebut adalah sebesar "modal yang disetor" atau "perubahannya" (net equity) ${ }^{15}$

Tata kelola dan tata tanggung jawab BUMN memiliki kapasitas hukum perdata dimana ketentuan yang mengaturnya adalah peraturan perundang-undangan yang bersifat perdata. Negara dalam kedudukannya pada BUMN adalah sebagai subyek hukum perdata, yang tindakan hukumnya semula dalam bentuk tugas dan kewenangan (taak en bevoegdheid) telah berubah menjadi hak dan kewajiban (bekwaamheid) sebagai akibat sebuah transaksi horisontal yang tunduk sepenuhnya pada rezim hukum perdata. ${ }^{16}$

\section{B. Hasil dan Pembahasan}

1. Terminologi Keuangan Negara dan Kerugian Keuangan Negara menurut Peraturan Perundangundangan

a. Terminologi Keuangan Negara Menurut Undang-Undang Nomor 19 Tahun 2003 tentang BUMN, BUMN terdiri dari 2 (dua) jenis, yaitu Perusahaan Perseroan (Persero) dan Perusahaan Umum (Perum). Pasal 1 angka 2 Undang-Undang Nomor 19 Tahun 2003, Persero adalah BUMN yang berbentuk Perseroan Terbatas yang modalnya terbagi dalam saham yang seluruh atau paling sedikit $51 \%$ (lima puluh satu persen) sahamnya dimiliki oleh Negara Indonesia yang tujuan utamanya mengejar keuntungan. Selanjutnya Pasal 1 angka 3 menyatakan bahwa Perum adalah BUMN yang seluruh modalnya dimiliki negara dan tidak terbagi atas saham, yang bertujuan untuk kemanfaatan umum berupa penyediaan barang dan/atau jasa yang bermutu tinggi dan sekaligus mengejar keuntungan berdasarkan prinsip pengelolaan perusahaan.

Modal BUMN merupakan dan berasal dari kekayaan negara yang dipisahkan. Hal tersebut diatur dalam Pasal 4 ayat (1) Undangundang Nomor 19 Tahun 2003. Adapun yang dimaksud dengan kekayaan negara yang dipisahkan menurut Pasal 1 angka 10 adalah kekayaan negara yang berasal dari Anggaran Pendapatan dan Belanja Negara (APBN) untuk dijadikan penyertaan modal negara pada Persero dan/atau Perum serta perseroan terbatas lainnya.

\footnotetext{
12. Ngadino, Agus dan Rumesten, Iza RS, "Pengelolaan Keuangan Negara dalam Perspektif Hukum Administrasi”, Jurnal Ilmiah Unsri yang diakses pada website eprints.unsri.ac.id/2277/1/agus_n_iza_05_2012, diakses 11 April 13. 2016 .

13. Ibid, hlm 84

14. Arifin P. Soeria Atmadja, 2013, Keuangan Publik dalam PerspektifHukum, Jakarta, Rajawali Press, hlm 119-120

15. Jamin Ginting, "Pengertian Merugikan Keuangan Negara dalam Tindak Pidana Korupsi", Jurnal Law Review 16. Fakultas Hukum UPH, Vol. VI, No.2, November 2006, hlm. 31.

16. Arifin P. Soeria Atmadja, 2014, Aktualisasi Hukum Keuangan Publik, Bandung, Mujahid Press, hlm 33
} 
Terminologi keuangan negara menurut Undang-Undang Nomor 17 Tahun 2003 tentang Keuangan Negara dapat dilihat dalam rumusan Pasal 1 angka 1, bahwa yang dimaksud dengan keuangan negara adalah semua hak dan kewajiban negara yang dapat dinilai dengan uang, serta segala sesuatu baik berupa uang maupun berupa barang yang dapat dijadikan milik negara berhubung dengan pelaksanaan hak dan kewajiban tersebut. Menurut Pasal 2 huruf g UndangUndang Nomor 17 Tahun 2003, keuangan negara antara lain menurut Pasal 1 angka 1, adalah:" kekayaan negara/kekayaan daerah yang dikelola sendiri atau oleh pihak lain berupa uang, surat berharga, piutang, barang, serta hak-hak lain yang dapat dinilai dengan uang, termasuk kekayaan yang dipisahkan pada perusahaan negara/ perusahaan daerah".

Terminologi keuangan negara sebagaimana dirumuskan dalam UndangUndang Nomor 17 Tahun 2003 tentang Keuangan Negara tersebut, khususnya Pasal 2 huruf $\mathrm{g}$ dan i pernah diajukan constitutional review ke Mahkamah Konstitusi, Mahkamah Konstitusi mengeluarkan Putusan Nomor 48/PUU-XI/2013. dan Nomor 62/PUU$\mathrm{XI} / 2013$. Kedua putusan Mahkamah Konstitusi tersebut menolak seluruhnya permohonan Pemohon terhadap permohonan constitutional review Pasal 2 huruf g dan i Undang-Undang Nomor 17 Tahun 2003 tentang Keuangan Negara terhadap Pasal 23 UUD NRI Tahun 1945 dan pasal-pasal lainnya yang dimohonkan oleh pemohon.

Ditegaskan oleh Mahkamah Konstitusi bahwa pada hakikatnya BUMN yang seluruh atau sebagian besar sahamnya merupakan milik negara adalah merupakan kepanjangan tangan negara dalam menjalankan sebagian fungsi negara untuk mencapai tujuan negara. Bahwa benar, kekayaan negara tersebut telah bertransformasi menjadi modal BUMN sebagai modal usaha yang pengelolaannya tunduk pada paradigma usaha (business judgement rules), namun pemisahan kekayaan negara tersebut tidak menjadikan beralih menjadi kekayaan BUMN yang terlepas dari kekayaan negara. Akibatnya tidak terjadi transformasi hukum keuangan negara/publik ke keuangan privat terhadap pengelolaan kekayaan negara yang dipisahkan pada BUMN.

Kedua Putusan Mahkamah Konstitusi tersebut mematahkan pendapat Arifin P. Soeria Atmadja, yang menyatakan bahwa telah terjadi transformasi status hukum uang negara dalam BUMN menjadi berstatus hukum uang perdata dan sebaliknya. Putusan Mahkamah Konstitusi yang bersifat final tersebut memberikan kepastian hukum terhadap terminologi keuangan negara yang terdapat pada BUMN.

Terminologi keuangan negara menurut Undang-Undang Nomor 31 Tahun 1999 juncto Undang-Undang Nomor 20 Tahun 2001 tentang Pemberantasan Tindak Pidana Korupsi, diatur dalam Penjelasan Umum Undang-Undang Nomor 31 Tahun 1999 yang menyatakan bahwa keuangan negara yang dimaksud adalah seluruh kekayaan negara dalam bentuk apapun, yang dipisahkan atau yang tidak dipisahkan, termasuk di dalamnya segala bagian kekayaan negara dan segala hak dan kewajiban yang timbul karena:

1) Berada dalam penguasaan, pengurusan, dan pertanggungjawaban pejabat lembaga negara, baik di tingkat pusat maupun di daerah;

2) Berada dalam penguasaan, pengurusan, dan pertanggungjawaban Badan Usaha Milik Negara/Badan Usaha Milik Daerah, yayasan, badan hukum, dan perusahaan yang menyertakan modal negara, atau perusahaan yang menyertakan modal pihak ketiga berdasarkan perjanjian dengan negara.

Rumusan tersebut secara substansial pada hakikatnya sama dengan rumusan Pasal 1 angka 1 dan Pasal 2 serta Penjelasan Umum angka 3 Undang-Undang Nomor 17 Tahun 2003 tentang Keuangan Negara. Rumusan keuangan negara pada kedua undang-undang tersebut mencakup pula kekayaan negara yang dipisahkan yang berada dalam penguasaan, pengurusan, dan pertanggungjawaban BUMN.

b. Terminologi Kerugian Keuangan Negara

Pasal 35 Undang-Undang Nomor 17 Tahun 2003 mengintepretasikan atau menganalogikan "kerugian keuangan negara" sama dengan "kerugian negara", sebagaimana berikut ini:

1) Setiap pejabat negara dan pegawai negeri 
bukan bendahara yang melanggar hukum atau melalaikan kewajibannya baik langsung atau tidak langsung yang merugikan keuangan negara diwajibkan mengganti kerugian dimaksud.

2) Setiap orang yang diberi tugas menerima, menyimpan, membayar, dan/atau menyerahkan uang atau surat berharga atau barang-barang negara adalah bendahara yang wajib menyampaikan laporan pertanggungjawaban kepada Badan Pemeriksa Keuangan.

3) Setiap bendahara sebagaimana dimaksud dalam ayat (2) bertanggung jawab secara pribadi atas kerugian keuangan negara yang berada dalam pengurusannya.

4) Ketentuan mengenai penyelesaian kerugian negara diatur di dalam undangundang mengenai perbendaharaan negara.

Terminologi "kerugian negara" yang digunakan berdasarkan rumusan UndangUndang Nomor 1 Tahun 2004 tentang Perbendaharaan Negara Pasal 1 angka 22 adalah bahwa: "kerugian negara/daerah adalah kekurangan uang, surat berharga, dan barang, yang nyata dan pasti jumlahnya sebagai akibat perbuatan melawan hukum baik sengaja maupun lalai." Penjelasan Umum angka 6 tentang Penyelesaian Kerugian Negara, menegaskan bahwa setiap kerugian negara/daerah yang disebabkan oleh tindakan melawan hukum atau kelalaian seseorang harus diganti oleh pihak yang bersalah. Dengan penyelesaian kerugian tersebut negara/daerah dapat dipulihkan dari kerugian yang telah terjadi.

\section{Pertanggungjawaban Direksi BUMN terhad a p e rbuatan yang Mengakibatkan Kerugian Keuangan Negara}

Menurut Penjelasan Pasal 2 angka 7 Undang-Undang Nomor 28 Tahun 1999 tentang Penyelenggara Negara yang Bersih dan Bebas dari Korupsi, Kolusi, dan Nepotisme, pada angka 1 ditegaskan bahwa Direksi, Komisaris, dan pejabat struktural lainnya pada BUMN dan BUMD merupakan penyelenggara negara. Hal ini karena mereka termasuk ke dalam kelompok pejabat yang mempunyai fungsi strategis dalam kaitannya dengan penyelenggaraan negara sesuai dengan ketentuan peraturan perundangundangan yang berlaku. Pejabat-pejabat BUMN tersebut bertanggungjawab untuk membawa BUMN sebagai agent of development dengan menggunakan paradigma business judgement rules dan prinsip good corporate governance. Pertanggungjawaban Direksi tersebut dapat dilihat dari adanya kesesuaian dalam pengelolaan perusahaan terhadap peraturan perundang-undangan dan prinsip-prinsip korporasi yang sehat. Berdasarkan hal tersebut, maka apabila Direksi dalam melakukan pengurusan BUMN menimbulkan akibat kerugian keuangan BUMN dikarenakan perbuatan melawan hukum baik sengaja maupun lalai, dapat diintepretasikan merugikan keuangan negara sepanjang memenuhi rumusan ketentuan peraturan perundang-undangan yang mengaturnya.

Dalam Hukum Administrasi Negara, rumusan merugikan keuangan negara diintepretasikan sama dengan kerugian negara. Hal tersebut dapat dilihat pada ketentuan Pasal 35 ayat (1) dan ayat (4) Undang-Undang Nomor 17 Tahun 2003 tentang Keuangan Negara; Pasal 1 angka 22, dan Pasal 59 sampai dengan Pasal 67 UndangUndang Nomor 1 Tahun 2004 tentang Perbendaharaan Negara; Pasal 20 ayat (4), ayat (5), dan ayat (6) Undang-Undang Nomor 30 Tahun 2014 tentang Administrasi Pemerintahan. Pengaturan tersebut mengatur tentang Tuntutan Perbendaharaan (TP) dan Tuntutan Ganti Rugi (TGR) keuangan negara/daerah non bendahara. Pasal 67 ayat (2) Undang-Undang Nomor 1 Tahun 2004 tentang Perbendaharaan Negara secara tegas menyatakan bahwa: "ketentuan penyelesaian kerugian negara/daerah dalam undangundang ini berlaku pula untuk pengelola perusahaan negara/daerah dan badan-badan lain yang menyelenggarakan pengelolaan keuangan negara, sepanjang tidak diatur dalam undang-undang tersendiri."

Menurut Pasal 20 ayat (2) dan ayat (6) Undang-Undang Nomor 30 Tahun 2014 tentang Administrasi Pemerintahan, Pejabat pemerintahan yang melakukan kesalahan administratif sehingga menimbulkan kerugian keuangan negara, harus mengembalikan kerugian negara tersebut 
apabila kesalahan administratif tersebut terjadi karena adanya unsur penyalahgunaan wewenang. Berdasarkan Peraturan Mahkamah Agung Nomor 4 Tahun 2015 tentang Pedoman Beracara dalam Penilaian Unsur Penyalahgunaan Wewenang, PTUN berwenang menilai sebelum adanya proses pidana. Jelaslah bahwa perbuatan direksi BUMN yang mengakibatkan kerugian keuangan negara dapat dikenai sanksi administratif dan/atau sanksi pidana. Hal tersebut secara eksplisit diatur dalam Pasal 64 ayat (1) Undang-Undang Nomor 1 Tahun 2004 tentang Perbendaharaan Negara. Ditegaskan lagi dalam ayat (2) bahwa putusan pidana tidak membebaskan dari tuntutan ganti rugi.

\section{Simpulan}

Berdasarkan penelitian yang telah dilakukan, maka dapat disimpulkan bahwa Direksi sebagai organ BUMN dipadankan dengan penyelenggara negara (pejabat negara) yang menjalankan fungsi strategis. Apabila Direksi BUMN melakukan perbuatan melawan hukum yang mengakibatkan kerugian keuangan negara, maka Direksi BUMN dapat dituntut berdasarkan ketentuan peraturan perundangundangan, karena kekayaan BUMN diintepretasikan sebagai kekayaan negara (keuangan negara). Di ranah Hukum Administrasi Negara hal tersebut diatur dalam Undang-Undang Nomor 17 Tahun 2003, Undang-Undang Nomor 1 Tahun 2004, Undang-Undang Nomor 15 Tahun 2004, dan Undang-undang Nomor 30 Tahun 2014. Dengan demikian, Direksi BUMN tersebut berkewajiban mengembalikan kerugian negara Namun apabila perbuatan Direksi BUMN tersebut memenuhi rumusan Pasal 2 dan Pasal 3 Undang-Undang Nomor 31 Tahun 1999 tentang Pemberantasan Tindak Pidana Korupsi karena ada unsur "secara melawan hukum" dapat merugikan keuangan negara, maka Direksi BUMN dapat dituntut berdasarkan ketentuan dalam ranah hukum pidana (tindak pidana korupsi). Dalam ranah tindak pidana korupsi, pengembalian kerugian keuangan negara atau perekonomian negara, tidak menghapuskan pidana pada pelaku tindak pidana tersebut.
Direksi BUMN dalam melaksanakan tugasnya harus selalu mematuhi anggaran dasar BUMN yang bersangkutan, peraturan perundang-undangan, serta prinsip-prinsip good corporate governance, agar dalam melaksanakan tugasnya tersebut tidak berbenturan dengan hukum, baik hukum administrasi negara maupun hukum pidana.

\section{Daftar Pustaka}

Ferry Makawimbang Hernold, 2014, Kerugian Keuangan Negara, Yogyakarta, Thafa Media

Ginting Jamin, "Pengertian Merugikan Keuangan Negara dalam Tindak Pidana Korupsi”, Jurnal Law Review Fakultas Hukum UPH, Vol. VI, No. 2 November 2006.

Hanitijo Soemitro Ronny, 1994, Metodologi Penelitian Hukum dan Yurimetri, Jakarta, Ghalia Indonesia.

Harian Kompas, 13 Februari 2016

Khairandy Ridwan dan Camelia Malik, 2007, Good Corporate Governance, Perkembangan Pemikiran dan Implementasinya di Indonesia dalam Perspektif Hukum, Yogyakarta, Total Media.

Marbun SF dan Moh. Mahfud MD, 1987, Pokok-pokok Hukum Administrasi Negara, Yogyakarta, Liberty

M. Hadjon Philipus, 2011, Hukum Administrasi dan Tindak Pidana Korupsi, Yogyakarta, Gadjah Mada University Press

Ngadino Agus dan Rumesten, Iza RS, "Pengelolaan Keuangan Negara $\mathrm{dalam} \mathrm{Perspektif} \mathrm{Hukum}$ Administrasi," Jurnal Ilmiah Unsri yang diakses pada website eprints.unsri.ac.id/2277/1/agus_n_iz a_05_2012, diakses pada tanggal 11 April 2016.

P. Soeria Atmadja Arifin, 2013, Keuangan Publik dalam Perspektif Hukum, Edisi Ketiga, Jakarta, Rajawali Press

P. Soeria Atmadja Arifin, 2014, Aktualisasi Hukum Keuangan Publik, Bandung, Mujahid Press

Tjandra W Riawan, 2008 , Hukum Administrasi Negara, Yogyakarta, 
Masalah - Masalah Hukum, Jilid 45 No. 4, Oktober 2016

Penerbit Universtas Atmajaya

Undang-Undang Dasar Negara Republik Indonesia Tahun 1945

Undang-Undang Nomor 28 Tahun 1999 tentang Penyelenggara Negara yang Bebas dari Korupsi, Kolusi, dan Nepotisme

Undang-Undang Nomor 31 Tahun 1999 jo. Undang-undang Nomor 20 Tahun 2001 tentang Pemberantasan Tindak Pidana Korupsi

Undang-Undang Nomor 17 Tahun 2003 tentang Keuangan Negara

Undang-Undang Nomor 19 Tahun 2003 tentang Badan Usaha Milik Negara

Undang-Undang Nomor 1 Tahun 2004 tentang Perbendaharaan Negara

Undang-Undang Nomor 30 Tahun 2014 tentang Administrasi Pemerintahan

Peraturan Mahkamah Agung Nomor 4 Tahun 2015 tentang Pedoman Beracara d a 1 a m P enila i a Un sur Penyalahgunaan Wewenang 